\title{
If you had less than a year to live, would you want to know? A seven-country European population survey of public preferences for disclosure of poor prognosis.
}

Running head: European citizens' preference to be told of poor prognosis

R. Harding ${ }^{\S 1}$, V. Simms ${ }^{1,2}$, N. Calanzani ${ }^{1}$, I. J. Higginson ${ }^{1}$, S. Hall ${ }^{1}$, M. Gysels ${ }^{3}$, A. Meñaca ${ }^{3}$, C. Bausewein ${ }^{1,4}$, L. Deliens ${ }^{45,6}$, P. Ferreira ${ }^{7}$, F. Toscani ${ }^{8}$, B. A. Daveson ${ }^{1}$, L. Ceulemans ${ }^{9}$, B. Gomes ${ }^{1}$, on behalf of PRISMA.

${ }^{1}$ King's College London, Cicely Saunders Institute, Department of Palliative Care, Policy \& Rehabilitation, London SE5 9PJ, UK.

${ }^{2}$ London School of Hygiene and Tropical Medicine, London, UK

${ }^{3}$ Barcelona Centre for International Health Research (CRESIB - Hospital Clínic), Universitat de Barcelona, Barcelona, Spain.

${ }^{4}$ Deutsche Gesellschaft für Palliativmedizin, Berlin, Germany.

${ }^{5}$ EMGO Institute for Health and Care Research, Palliative Care Center of Expertise and Department of Public and Occupational Health, VU University Medical Center, Amsterdam, the Netherlands.

${ }^{6}$ End-of-Life Care Research Group, Ghent University \& Vrije Universiteit Brussel, Brussels, Belgium.

${ }^{7}$ Centre for Health Studies and Research, University of Coimbra (CEISUC), Coimbra, Portugal.

${ }^{8}$ Istituto di Ricerca in Medicina Palliativa, Fondazione Lino Maestroni -ONLUS, Cremona, Italy.

${ }^{9}$ University of Antwerp, Antwerp, Brussels.

$\S$ Corresponding author: Richard Harding, King's College London, Cicely Saunders Institute, Department of Palliative Care, Policy \& Rehabilitation, Bessemer Road, London SE5 9PJ Email: richard.harding@ kcl.ac.uk ; Tel:+44 (0)207848 5518; Fax:+44 (0)207848 5517 


\begin{abstract}
Objective

With increasing European cancer deaths, clinicians must manage information regarding poor prognosis. This study aimed to determine European citizens' preferences, within a scenario of serious illness such as cancer with less than a year to live, for information disclosure regarding poor prognosis, the likely symptoms and problems, and the care options available, to measure variations between countries, and to identify factors associated with preferences.
\end{abstract}

\title{
Methods
}

A population-based cross-national telephone survey using random digit dialling in seven countries.

\section{Results}

Among 9,344 respondents, data revealed an international preference (73.9\%) to always be informed in the scenario of having a serious illness such as cancer with less than a year to live. This varied from $67.6 \%$ in Italy to $80.7 \%$ in Flanders. A minority (21.1\%), ) did not want such information unless they ask/ at all. People under 70 (OR 0.72, 95\% CI 0.62-0.83, $\mathrm{p}<0.001)$, men (OR 1.23, 95\% CI 1.10-1.37, $\mathrm{p}<0.001)$, those with experience of illness $(\mathrm{OR}=1.20 .95 \%$ CI 1.01-1.43, $\mathrm{p}<0.05)$ and with more education $(\mathrm{OR}=1.20,95 \%$ CI 1.09 $1.32, \mathrm{p}<0.001)$ were more likely to want to know of limited time left.

\section{Conclusions}

The models confirmed the influence of four factors in more than one country (age, gender, education and most concerning problem) and added 11 country-specific factors to which national policies and clinical practice should respond. These findings confirm a majority public preference to be informed in a scenario of poor prognosis. Policy clinical practice should facilitate elucidation and delivery of preferences. Evidence for effective communication skills-building interventions for clinicians is required.

Keywords: Cancer, oncology, prognosis, information, Europe, preferences.

\section{Introduction}

With an ageing European population and an annual 1.7 million cancer deaths in Europe[1], clinicians increasingly need to manage information-giving in the face of poor prognosis. Information is a primary need in advanced cancer[2]. Although being able to control the content and extent of information is important to care recipients in the context of cancer[3], it is difficult to formulate and pose sensitive questions to clinicians without being prompted[4]. Clinicians also feel unsure how much information to provide and when [5], often do not share prognostic information[6], and report waiting to be asked[3]. As a result the condition is misunderstood by those affected $[7,8]$ which may increase anxiety, reduce the potential for advance care planning, and increase the likelihood of unplanned admissions.

The evidence is equivocal on how much information is wanted in advanced disease [8]. With increased public access via the internet to health-related information of variable quality, it is essential that accurate information specific to an individual's situation is available when wanted. Information-giving is an essential aspect of clinical care, and understanding public preferences for information in advanced disease is necessary to train and support clinicians in responding appropriately. From a public health perspective, it is also important to educate the 
public concerning the importance of communicating their preferences to their health care providers. As more people die at an advanced age, clinicians will be increasingly confronted with patients that lack mental capacity, hence early effective information giving becomes more important.

European medical cultures may be changing from a historical point of concealment of prognostic information justified by beneficence[9]. Differences persist within and between European populations, with recent evidence revealing that in addition to age, personal values and circumstance, country of residence also influences preferred place of death[10]. However, little is known about preferences for prognostic information among European populations, and the variations between them. Moreover, little is known on how exposure to illness, caregiving and age may affect preferences. Evidence from Europe is needed to appraise and inform national and international care practices. The present study is the first to cross-nationally determine variations in people's preferences for information regarding prognosis in a scenario of advanced cancer.

This study aimed to determine the preferences of European citizens for disclosure of information regarding a poor prognosis, the likely symptoms and problems, and the care options available. The study further aimed to measure variations between countries, and to identify factors associated with preferences.

\section{Methods}

Design

A population-based cross-national telephone survey in seven European countries. The details of the survey are described elsewhere and it was undertaken as part of a pan-European clinical academic programme to enhance end-of-life cancer care for European citizens[10, $11]$.

\section{Questionnaire}

\section{Development}

We took a multi-method approach to questionnaire development to enhance validity and comparability. This included: (a) review of studies and questions on end-of-life care (EoLC) preferences and priorities; (b) review of cross-national social surveys; (c) three consultation rounds with 27 EoLC expert researchers and clinicians.

\section{Content}

The questionnaire included 28 items on preferences, personal values related to EoLC, experience with illness, death and dying, general health and sociodemographics. Preferences were asked in a scenario imagining 'a situation of serious illness, for example cancer, with less than one year to live'. Most demographic items were adapted from the European Social Survey Round 4 (2008) [12].

The first three survey questions are the outcomes reported in this paper: 1 . would you like to be informed that you had limited time left?; 2. would you like to be informed about what symptoms and problems you were likely to experience?; 3 . would you like to be informed about the options available for care and how they might affect you? These options might be services available, places where you could be looked after, treatments and medication." Possible responses were 'Yes, always', 'Yes, but only if you ask about it', 'No' and 'You don't know'. The three outcomes are referred to as 1. 'time left', 2. 'symptoms' and 3. 'care options'. 


\section{Translation}

We undertook systematic and culture-sensitive translations of the questionnaire into the countries' dominant language following European Organisation for Research and Treatment in Cancer (EORTC) translation procedures[13]. This involved forward independent translations by two native-speakers with EoLC knowledge, backward professional translation and harmonisation of all versions.

Testing

The resulting questionnaire (in supplementary data) was piloted using cognitive interviewing to check how items are interpreted with 30 volunteers in England and Germany[14].

\section{Setting}

The survey covered Flanders (the Dutch-speaking part of Belgium) and all regions in England, Germany, Italy, Netherlands, Spain and Portugal. These countries have contrasting cultural, political contexts and sociodemographic profiles[15-18].

\section{Participants}

Individuals aged $\geq 16$ residing in a household were invited to participate in a computer assisted telephone interview (CATI) by selection of households using random digit dialling (RDD). Once an eligible participant was identified, no substitution was allowed. Exclusion criteria were: incapacity to hear or understand the information and provide informed consent (assessed by interviewers), and language skills that hindered survey participation (using the country's dominant language).

To be able to detect previous age differences in preferences for home death in England between those aged 16-44 (60\%) and those aged 45+ (51\%)[19], we needed a minimum of 1,278 completed interviews (power 0.90, significance 0.05). Modelling calculations to other countries resulted in overall minimum needed interviews being 8,946. No oversampling, strata or quota were applied.

\section{Procedures}

The lead academic team trained 149 interviewers (95\% native-speakers) from two commercial research agencies with experience in telephone surveys on social and health issues on how to administer the questionnaire. Interviews were conducted from May to December 2010 with at least four call attempts (at least one after $6 \mathrm{pm}$ ). Interviewers entered answers into a database with missing data checks at entry; $10 \%$ of interviews were checked by in-situ supervisors.

\section{Ethical approval}

The study was approved by the research ethics committee of the lead academic centre, King's College London (ref. BDM/08/09-48). Local research ethics approvals or notifications to national data protection agencies as applicable were obtained in all countries.

\section{Analysis}

The analysis was conducted by VS using Stata 10.1. Participant characteristics were presented by country for sociodemographic, experiential and opinion variables. For each of the three outcomes, the proportion of each possible response was calculated overall and by country. 
The primary outcome (wish to know that there was limited time left) was converted into a binary score (yes always $=1$ vs all other options $=0$ ). Prevalence of wish to know was presented by covariate and country for 17 independent variables identified in the literature as possibly associated with information and decision-making preferences at the end of life. The independent variables were grouped as follows. Sociodemographic: gender (binary), age band (ordinal), education (ordinal: up to age 16, age 16-18, post-18), living area (ordinal: city, suburb, town, village/rural), general health (ordinal: 5-point scale), marital status (categorical), living in country of birth (binary), length of time in country (ordinal), financial hardship (ordinal: 4 categories), and living alone (binary). Illness experience in the past five years: serious illness of a close/relative friend (binary), death of a close relative/friend (binary), diagnosis of serious illness (binary), ever cared for a relative/friend in the last few months of their life (binary). Opinions: preference for quality or quantity of life (ordinal: 3 categories), most concerning problem (binary: physical/psychological vs social), prefer to die at home (binary).

The significance of variations in preferences by each of the 17 independent variables within and across countries was determined using $\mathrm{x}^{2}$ tests or Fisher's Exact Test when required for categorical data, Mann-Whitney $U$ tests for ordinal data and t-tests for continuous data. Any variables associated with the outcome at a significance level of $p<0.1$ for all countries combined, with shared directionality in a majority of countries, was carried forward into multivariate analysis.

Time-series logit analysis was conducted to identify influencing factors in each scenario, with country designated the panel variable. This analysis allowed for the relative influence of multiple independent variables on the dependent variable, adjusting for any confounding effect on each other. Potential explanatory variables were entered in the model and retained in a second step if significant $(\mathrm{p}<0.05)$. The odds ratio of each variable value was examined to determine directionality and linearity. Finally, each outcome was tabulated against the other two (time left with symptoms, time left with care options, and symptoms with care options), and $\mathrm{x}^{2}$ tests were used to measure the association between responses with significance level of $\mathrm{p}<0.05$. 


\section{Results}

Sample description

The demographic characteristics of the sample are displayed by country in Table 1.

\section{INSERT TABLE 1 HERE}

From a total of 45,242 randomly selected households with a known eligible person, 9,344 people (21\%) agreed to participate in the study. Response was highest in Germany (29\%), followed by Portugal (28\%), Spain (21\%), Italy (21\%), England (21\%), Flanders (16\%) and Netherlands (16\%). Overall, $1 \%$ were excluded due to language difficulties, $1 \%$ due to hearing problems and $1 \%$ were deemed incapable of providing informed consent.

Main reasons for refusal were lack of interest (59\%), lack of time (17\%) and refusal to generally take part in telephone surveys $(3 \%)$. In addition, three per cent $(n=1,251)$ stated reasons for refusal to participate related to the topic: 497 because they had a physical disability or illness; 385 due to its sensitive nature; 223 because a relative or friend had a physical disability or illness; 146 due to a recent household bereavement/death. In 3\%, reasons for refusal were not specified. In addition, $7 \%$ asked to be called back but the interview was never concluded, $8 \%$ broke-off the interview at early stages and $<1 \%$ chose to stop and withdrew their information.

The interview took 15.4 minutes on average to complete. The oldest person interviewed was 95 years old, $13 \%$ participants were 70 years or older and $93 \%$ were born in the country they currently lived in. 10\% reported having been seriously ill in the past five years, and $53 \%$ had cared for a close relative or friend in their last months of life (Table 2).

\section{Descriptive analysis}

Across the whole sample, $73.9 \%$ of respondents would always want to know if they had limited time left, $13.6 \%$ would only want to be told if they asked, and $7.5 \%$ would not want to be informed (Table 2). More than four-fifths $(81.3 \%)$ would always want to be informed about symptoms, and $89.5 \%$ would always want to be informed of their care options. The proportion always wanting to know they had limited time left varied from $67.6 \%$ in Italy to $80.7 \%$ in Flanders. The proportion wanting to know about symptoms was also lowest in Italy (76.9\%), and highest in Portugal (89.6\%), while a wish to know about care options ranged from $82.8 \%$ in the Netherlands to $94.9 \%$ in Portugal.

\section{INSERT TABLE 2 HERE}

\section{Associations of categorical outcomes with independent variables}

With respect to age, all outcomes showed a similar distribution; in the 16-69 range there was a slight peak in the middle but little variation, while the 70+ group were substantially less likely to want information (See Table B in supplementary material). All three outcomes were significantly associated with age $(\mathrm{p}<0.001)$ using $\mathrm{x}^{2}$ tests (time left, $\mathrm{x}^{2}=91.64$; symptoms, $\mathrm{x}^{2}=113.92$; care options, $\left.\mathrm{x}^{2}=157.54\right)$.

People with higher educational attainment were more likely to want to know all information, either always or if they asked, and more likely to have a view (i.e. less likely to respond 
'don't know'). Education was significantly associated ( $\mathrm{p}<0.001)$ with all outcomes (time left, $x^{2}=139.77$; symptoms, $x^{2}=96.43$; care options, $x^{2}=101.21$ ).

Those living alone were less likely to want to know about symptom burden or care options. Living alone was not associated with wish to know about time left $\left(x^{2}=3.84, p=0.279\right)$, but significantly associated $(\mathrm{p}<0.001)$ with wish to know about symptoms $\left(\mathrm{x}^{2}=20.50\right)$ and care $\left(\mathrm{x}^{2}=37.30\right)$.

\section{Association of binary outcome with independent variables by country}

The main outcome, wish to know if there was limited time left, was coded binary and tabulated against independent variables by country (Table 3 ).

Overall men were more likely to wish to know, and this association was statistically significant in five countries (England, Germany, Italy, Portugal and Spain) and maintained the same direction in a sixth (Netherlands). Flanders was the exception in that women were significantly more likely to want to know about limited time left.

Widowed people were less likely to want to know if there was limited time left, overall and in five countries (although this only reached statistical significance for the Netherlands), but in Italy the reverse was true.

Education was associated with greater probability of the outcome in all countries, reaching statistical significance in four countries (Flanders, England, Netherlands and Spain). Overall, financial hardship was associated with lower probability of the outcome, but this association was not significant in any single country.

In Italy and Portugal, participants whose main concerns were social were more likely to want to know about limited time left, but in other countries and overall there was no association. Those who prioritised quality over extension of life had higher probability of wanting time left information in five countries (Flanders, England, Germany, Netherlands and Italy), but the reverse was true in Portugal. There was no association between this outcome and preferred place of death.

People who had been diagnosed with a serious illness in the past five years were more likely to want to know about limited time left in five countries (England, Germany, Netherlands, Italy, Portugal), and the other two (Flanders, Spain) showed very small differences. Severe illness in a close relative or friend was also associated with the outcome, except in Italy.

\section{INSERT TABLE 3 HERE}

\section{Multivariate model}

Any variables associated with the outcome at a significance level of $\mathrm{p}<0 \cdot 1$ for all countries combined, with shared directionality in a majority of countries, was carried forward into multivariate analysis. The following variables met these criteria: age, gender, marital status, education, finances, quality vs quantity of life, serious illness in self, and relative with serious illness.

Age did not show a clear overall trend in bivariate analysis, but the oldest group was clearly distinct from the others and this created significant associations. Therefore age was analysed as categorical using dummy variables. Only the oldest age group was associated with the outcome, so the variable was recoded to binary, with 16-69 compared to 70+. Marital status was also analysed as categorical because the options were not ordered.

Wanting to know about limited time left was significantly more likely among people aged under $70(\mathrm{OR}=0.72)$, men $(\mathrm{OR}=1.23)$, those with more education $(\mathrm{OR}=1.20)$, those with experience of serious illness in themselves $(\mathrm{OR}=1.20)$ or in others $(\mathrm{OR}=1.12)$, and those 
who prioritised quality over quantity of life $(\mathrm{OR}=1.13)$ (Table 4). Therefore age had the greatest effect. The difference between countries was statistically significant $(p<0.001)$.

\section{INSERT TABLE 4 HERE}

\section{Associations between outcomes}

There was a high degree of association between the three outcomes $\left(x^{2}\right.$ over 1000 in all three tests, $\mathrm{p}<0.001)$. Participants who wanted information in any area were more likely to want information in the other two (Table 5). However, many people wanted selective information. Of those who did not want to be told if they had limited time left, less than half $(41.8 \%)$ wished to be told their probable symptoms, but two thirds $(67.1 \%)$ wanted to know their care options. The question regarding time left had the highest prevalence of 'don't know' responses in the entire questionnaire. Participants who did not know whether they would want to be informed if they had limited time left were likely to say they would always want to know their symptoms $(58.2 \%)$ and care options $(81.3 \%)$.

INSERT TABLE 5 HERE 


\section{Discussion}

Our data have revealed an international majority public preference to always be informed in the scenario of having a serious illness with less than a year to live. However, the preference to know about remaining time left (overall 73.9\%) was smaller than both desire for knowledge about possible symptoms (81.3\%), and for care options $(89.5 \%)$. Although a strong correlation was found between the three outcomes, even among those who would not want to know if they had limited time left, the majority $(67.1 \%)$ would always want to know the care options available to them.

These data provide important evidence that clinicians should anticipate patients wanting full knowledge on their prognosis, disease presentation and care (although a minority varying by country do not wish to know unless they ask, or at all, with a quarter overall not wanting information on prognosis). The analysis also found that people under 70 , men, those with experience of illness and with higher educational attainment were more likely to want to know if they had limited time left.

It is notable that the three countries with the lowest percentage of respondents who would wish to know about time left were Italy, Spain and Portugal. It has been suggested that in traditional Mediterranean Catholic countries patients are more likely to reject autonomy and that the medical establishment may have a greater paternalism[20].

These findings now demand evidence of appropriate and effective communication skills to enable clinicians to elicit preferences, and of information-giving. A systematic review of clinician-patient communication [21] found little definitive evidence to support one communication method over any other. Clinicians should be adequately equipped from medical and nursing training curricula to manage information disclosure. However, evidence suggests that although communication training is effective in terms of skill acquisition, this is less well applied in practice[22].

The skill needed in eliciting preferences and sharing information also needs to extend to those who may not be clear on whether they would want information to be shared with them. One in 20 people did not know whether they'd want to know about time left, and this was less common for other questions. That people were unable to make a hypothetical decision does not necessarily translate to a real situation of having a serious illness such as cancer. However, it is interesting that in the multivariate analysis personal experience of a serious illness increased the likelihood of wanting to know about time left.

Age was a very important covariate in our place of death study[10]. Three effects are potentially related to each other with respect to birth cohort effect, health status, and covariates. Older people are more likely to have health problems, to be retired, and widowed. It is difficult to disentangle these effects.

These findings derive from a robust cross-national comparison. We used standard methodologies and asked identical questions across countries (reducing differential biases). The results not only provide country-specific factors and local preferences (important since most policies are made at national level), but also cross-national data to inform international policy making.

However, the study has also some limitations. Our response rate is typical of the declining rates of RDD surveys [23], though in some countries our response rate is higher than the rates in the 2002 Picker Institute Europe survey of public views on health care responsiveness[24]. Our sample presents well known selection biases excluding those living in households without a fixed telephone (29\% of households in the EU-27)[24] and over-representing women and older people due to selective non-response. The bias towards women may have reduced estimates, as men were more likely to want information on time left. 
Notwithstanding, these limitations have little effect on the main aim of cross-national comparisons.

For some of the healthier participants and as identified in the pilot stages of the questionnaire[14], it might have been difficult to imagine the actual circumstances surrounding the dying process and preceding months. However we aimed to minimise this through the use of a well-conceived hypothetical scenario. Also, this might have been easier for people with a previous experience of caring for someone close to them in the last months of life (53\% of our sample). Experiences of a diagnosis of serious illness in self or in another were associated with the outcome of wanting to know about time left, suggesting that those who made a hypothetical choice in the absence of experience may be likely to choose information in the presence of serious illness. Data from Australian patients with metastatic disease reported a slightly lower preference than reported in our survey (65\% vs $73.9 \%)$ to know about 1 year survival.[25] Data from Brazilian patients with advanced cancer found that the vast majority (92\%) believed that patients should know their poor prognosis, although interestingly only around one-third had been informed themselves. [26] A further study from Korea of advanced cancer patients found a majority preference for prognosis disclosure (78.6\%). [27] However, among cancer outpatients in Japan, a study reported only $50.4 \%$ of the sample reported preferring to know about time left. [28] Therefore it seems that the hypothetical/real scenario may be less clearly related to preference that culture and context. We also recognise that although there may be a preference to know about poor prognosis, the evidence suggests that accurate prognostication is difficult. [29] The country models help understand within-country diversity. The models confirmed the influence of four factors in more than one country (age, gender, education and most concerning problem) and added 11 country-specific factors to which national policies and clinical practice should be responsive.

Replicating the survey with patients at different stages of illness would help determine if and how hypothetical and 'real' preferences differ. Policy should now reflect the majority preference for full information on time left, likely symptoms and care options, as well as putting adequate care options in place for patients with advanced disease.

\section{Acknowledgements}

We are most grateful to all the survey participants. We thank the European Commission for the financial support needed to undertake this study; BMG Research and ZEM University of Bonn for assistance in survey administration and data collection; Gao Wei and Joana Cadima for statistical advice. We also thank our colleagues from PRISMA including the scientific committee who contributed to discussions and scientific review of the survey, namely Hamid Benalia, Emma Bennett, Lucy Bradley, Noël Derycke, Martine de Vlieger, Let Dillen, Natalie Evans, Michael Echteld, Nancy Gikaara, Stein Kaasa, Johan Menten, Bregje Onwuteaka-Philipsen, Ana Barros Pinto, Robert Pool, Richard A. Powell, Miel Ribbe, Katrin Sigurdardottir, Bart Van den Eynden, Paul Vanden Berghe and Trudie van Iersel. We thank Susana Bento, Carolina Comabella, Filomena Ferreira, Grethe Iversen, Carmen LópezDóriga, Constanze Rémi, Christian Schulz and Wessex Translations for their work translating and back translating the questionnaires. The invaluable work of Ron Irwin, Sian Best and Mike Gover at King's College London is also highly appreciated.

\section{Funding}


This work was supported by the European Commission's Seventh Framework Programme [contract number: Health-F2-2008-201655]. PRISMA was funded by the European Commission's Seventh Framework Programme with the overall aim to co-ordinate highquality international research into end-of-life cancer care. PRISMA aims to provide evidence and guidance on best practice to ensure that research can measure and improve outcomes for patients and families. PRISMA activities aim to reflect the preferences and cultural diversities of citizens, the clinical priorities of clinicians, and appropriately measure multidimensional outcomes across settings where end-of-life care is delivered. Principal Investigator: Richard Harding. Scientific Director: Irene J Higginson. This article reflects only the author's views and the European Commission is not liable for any use that may be made of the information contained therein. The funder had no role in the study design, in the collection, analysis and interpretation of data; in the writing of this manuscript; or in the decision to submit this manuscript for publication.

\section{Conflict of Interest}

The authors have declared no conflicts of interest.

\section{Reference List}

1. Higginson, I.J. and M. Costantini, Dying with cancer, living well with advanced cancer. European Journal of Cancer, 2008. 44(10): p. 1414-1424.

2. Wenrich, M.D., et al., Communicating with dying patients within the spectrum of medical care from terminal diagnosis to death. Arch Intern Med, 2001. 161(6): p. 868-74.

3. Clayton, J.M., P.N. Butow, and M.H.N. Tattersall, When and How to Initiate Discussion About Prognosis and End-of-Life Issues with Terminally Ill Patients. Journal of Pain and Symptom Management, 2005. 30(2): p. 132-144.

4. Street Jr, R.L., Information-giving in medical consultations: The influence of patients' communicative styles and personal characteristics. Social Science \&amp; Medicine, 1991. 32(5): p. 541-548.

5. Fitch, M.I., How much should I say to whom? J Palliat Care, 1994. 10(3): p. 90-100.

6. Schulman-Green, D., et al., Nurses' communication of prognosis and implications for hospice referral: a study of nurses caring for terminally ill hospitalized patients. Am J Crit Care, 2005. 14(1): p. 64-70.

7. Mackillop, W.J., et al., Cancer patients' perceptions of their disease and its treatment. Br J Cancer, 1988. 58(3): p. 355-8.

8. Gaston, C.M. and G. Mitchell, Information giving and decision-making in patients with advanced cancer: a systematic review. Soc Sci Med, 2005. 61(10): p. 2252-64.

9. Mauri, E., et al., An exploratory study on the Italian patients' preferences regarding how they would like to be told about their cancer. Support Care Cancer, 2009. 17(12): p. 1523-30.

10. Gomes, B., et al., Preferences for place of death if faced with advanced cancer: a population survey in England, Flanders, Germany, Italy, the Netherlands, Portugal and Spain. Ann Oncol, 2012. 
11. Harding, R. and I.J. Higginson, PRISMA: a pan-European co-ordinating action to advance the science in end-of-life cancer care. Eur J Cancer, 2010. 46(9): p. 1493501.

12. Jowell, R., Measuring attitudes cross-nationally: Lessons from the European Social Survey2007: Sage.

13. Cull, A., et al., EORTC Quality of Life Group Translation Procedure, 2002, EORTC Quality of Life Group Publication: Brussels.

14. Daveson, B.A., et al., Constructing understandings of end-of-life care in Europe: a qualitative study involving cognitive interviewing with implications for cross-national surveys. J Palliat Med, 2011. 14(3): p. 343-9.

15. Hall, S., et al., Palliative care for older people: better practices., W.H.O.R.O.f. Europe, Editor 2011: Copenhagen.

16. Cohen, J., et al., Which patients with cancer die at home? A study of six European countries using death certificate data. J Clin Oncol, 2010. 28(13): p. 2267-73.

17. Inglehart, R. and C. Welzel, Changing mass priorities: the link between modernization and democracy. . Perspectives on Politics, 2010. 8(2): p. 551-567.

18. Busse, R., et al., Tackling chronic disease in Europe: strategies, interventions and challenges. , in Observatory Study series, http://www.cureacasa.it/files/bio2/10.pdf, Editor 2010: Copenhagen.

19. Higginson, I., Priorities and preferences for end-of-life care. , 2003: London.

20. Toscani, F. and C. Farsides, Deception, catholicism, and hope: understanding problems in the communication of unfavorable prognoses in traditionally-catholic countries. Am J Bioeth, 2006. 6(1): p. W6-18.

21. Rodin, G., et al., Clinician-patient communication: a systematic review. Supportive Care in Cancer, 2009. 17(6): p. 627-644.

22. Gysels, M., A. Richardson, and I.J. Higginson, Communication training for health professionals who care for patients with cancer: a systematic review of effectiveness. Support Care Cancer, 2004. 12(10): p. 692-700.

23. Kempf, A.M. and P.L. Remington, New challenges for telephone survey research in the twenty-first century. Annu Rev Public Health, 2007. 28: p. 113-26.

24. Communication., D.-G.f., E-communications household survey. , in Special Eurobarometer 293, http://ec.europa.eu/public_opinion/archives/ebs/ebs_293_full_en.pdf, Editor 2008.

25. Hagerty, R.G., et al., Cancer patient preferences for communication of prognosis in the metastatic setting. J Clin Oncol, 2004. 22(9): p. 1721-30.

26. Fumis, R.R., B. De Camargo, and A. Del Giglio, Physician, patient and family attitudes regarding information on prognosis: a Brazilian survey. Ann Oncol, 2012. 23(1): p. 205-11.

27. Yun, Y.H., et al., Experiences and attitudes of patients with terminal cancer and their family caregivers toward the disclosure of terminal illness. J Clin Oncol, 2010. 28(11): p. 1950-7.

28. Fujimori, M., et al., Preferences of cancer patients regarding the disclosure of bad news. Psycho-Oncology, 2007. 16(6): p. 573-81.

29. Moss, A.H., et al., Prognostic significance of the "surprise" question in cancer patients. Journal of Palliative Medicine, 2010. 13(7): p. 837-40. 

Table 1 Participant characteristics by country

\begin{tabular}{|c|c|c|c|c|c|c|c|c|}
\hline $\mathrm{n}$ & $\begin{array}{c}\text { England } \\
1,351\end{array}$ & $\begin{array}{c}\text { Flanders } \\
1,269\end{array}$ & $\begin{array}{c}\text { Germany } \\
1,363\end{array}$ & $\begin{array}{l}\text { Italy } \\
1,352\end{array}$ & $\begin{array}{c}\text { Netherlands } \\
1,356\end{array}$ & $\begin{array}{c}\text { Portugal } \\
1,286\end{array}$ & $\begin{array}{c}\text { Spain } \\
1,367\end{array}$ & $\begin{array}{c}\text { All } \\
\text { countries } \\
\mathbf{9 , 3 4 4}\end{array}$ \\
\hline \multicolumn{9}{|l|}{ Age } \\
\hline $\begin{array}{l}\text { Mean in years } \\
(\mathrm{SD})\end{array}$ & $54 \cdot 2(16 \cdot 3 \%)$ & $52 \cdot 2(14 \cdot 3 \%)$ & $\begin{array}{c}47 \cdot 1 \\
(15 \cdot 7 \%)\end{array}$ & $\begin{array}{c}48 \cdot 7 \\
(15.9 \% \%)\end{array}$ & $54 \cdot 5(14 \cdot 6 \%)$ & $\begin{array}{c}50 \cdot 1 \\
(16 \cdot 9 \%)\end{array}$ & $\begin{array}{c}48 \cdot 1 \\
(16 \cdot 5 \%)\end{array}$ & $\begin{array}{c}50 \cdot 7 \\
(16 \cdot 0 \%)\end{array}$ \\
\hline $16-29$ & $107(8 \cdot 0 \%)$ & $88(7 \cdot 5 \%)$ & $213(15 \cdot 8 \%)$ & $\begin{array}{c}177 \\
(15 \cdot 0 \%)\end{array}$ & $61(4 \cdot 7 \%)$ & $\begin{array}{c}169 \\
(13 \cdot 8 \%)\end{array}$ & $204(15 \cdot 4 \%)$ & $\begin{array}{c}1019 \\
(11 \cdot 5 \%)\end{array}$ \\
\hline $30-39$ & $151(11 \cdot 3 \%)$ & $119(10 \cdot 2 \%)$ & $197(14 \cdot 6 \%)$ & $\begin{array}{c}166 \\
(14 \cdot 1 \%)\end{array}$ & $126(9.7 \%)$ & $\begin{array}{c}176 \\
(14 \cdot 4 \%)\end{array}$ & $213(16 \cdot 1 \%)$ & $\begin{array}{c}1148 \\
(12 \cdot 9 \%)\end{array}$ \\
\hline $40-49$ & $255(19 \cdot 1 \%)$ & $261(22 \cdot 3 \%)$ & $361(26 \cdot 8 \%)$ & $\begin{array}{c}241 \\
(20 \cdot 4 \%)\end{array}$ & $289(22 \cdot 3 \%)$ & $\begin{array}{c}231 \\
(18 \cdot 9 \%)\end{array}$ & $279(21 \cdot 0 \%)$ & $\begin{array}{c}1917 \\
(21 \cdot 6 \%)\end{array}$ \\
\hline $50-59$ & $258(19 \cdot 4 \%)$ & $315(27 \cdot 0 \%)$ & $273(20 \cdot 3 \%)$ & $\begin{array}{c}272 \\
(23 \cdot 1 \%)\end{array}$ & $313(24 \cdot 2 \%)$ & $\begin{array}{c}246 \\
(20 \cdot 1 \%)\end{array}$ & $294(22 \cdot 2 \%)$ & $\begin{array}{c}1971 \\
(22 \cdot 2 \%)\end{array}$ \\
\hline $60-69$ & $317(23 \cdot 8 \%)$ & $256(21 \cdot 9 \%)$ & $184(13 \cdot 7 \%)$ & $\begin{array}{c}209 \\
(17 \cdot 7 \%)\end{array}$ & $306(23 \cdot 6 \%)$ & $\begin{array}{c}226 \\
(18 \cdot 5 \%)\end{array}$ & $198(14 \cdot 9 \%)$ & $\begin{array}{c}1696 \\
(19 \cdot 1 \%)\end{array}$ \\
\hline $70+$ & $244(18 \cdot 3 \%)$ & $129(11 \cdot 0 \%)$ & $119(8 \cdot 8 \%)$ & $115(9.7 \%)$ & $199(15 \cdot 4 \%)$ & $\begin{array}{c}175 \\
(14 \cdot 3 \%)\end{array}$ & $139(10 \cdot 5 \%)$ & $\begin{array}{c}1120 \\
(12 \cdot 6 \%)\end{array}$ \\
\hline \multicolumn{9}{|l|}{ Gender } \\
\hline Female & $863(63 \cdot 9 \%)$ & $832(65 \cdot 6 \%)$ & $790(58 \cdot 0 \%)$ & $\begin{array}{c}974 \\
(72 \cdot 0 \%)\end{array}$ & $891(65 \cdot 8 \%)$ & $\begin{array}{c}893 \\
(69 \cdot 4 \%)\end{array}$ & $935(68 \cdot 4 \%)$ & $\begin{array}{c}6178 \\
(66 \cdot 1 \%)\end{array}$ \\
\hline \multicolumn{9}{|l|}{$\begin{array}{l}\text { Living } \\
\text { arrangements }\end{array}$} \\
\hline Living alone & $325(24 \cdot 2 \%)$ & $197(15 \cdot 6 \%)$ & $281(20 \cdot 8 \%)$ & $\begin{array}{c}142 \\
(10 \cdot 5 \%)\end{array}$ & $294(21 \cdot 8 \%)$ & $\begin{array}{c}136 \\
(10 \cdot 6 \%)\end{array}$ & $156(11 \cdot 5 \%)$ & $\begin{array}{c}1531 \\
(16 \cdot 5 \%)\end{array}$ \\
\hline \multicolumn{9}{|l|}{$\begin{array}{l}\text { Urbanisation } \\
\text { level }\end{array}$} \\
\hline $\begin{array}{l}\text { Big city or } \\
\text { suburbs/ outskirts }\end{array}$ & $500(37 \cdot 1 \%)$ & $289(22 \cdot 8 \%)$ & $556(40 \cdot 9 \%)$ & $\begin{array}{c}269 \\
(19.9 \%)\end{array}$ & $363(26 \cdot 8 \%)$ & $\begin{array}{c}643 \\
(50 \cdot 0 \%)\end{array}$ & $324(23 \cdot 7 \%)$ & $\begin{array}{c}2944 \\
(31 \cdot 5 \%)\end{array}$ \\
\hline
\end{tabular}




\begin{tabular}{|c|c|c|c|c|c|c|c|c|}
\hline $\mathrm{n}$ & $\begin{array}{c}\text { England } \\
1,351\end{array}$ & $\begin{array}{c}\text { Flanders } \\
1,269\end{array}$ & $\begin{array}{c}\text { Germany } \\
1,363\end{array}$ & $\begin{array}{l}\text { Italy } \\
1,352\end{array}$ & $\begin{array}{c}\text { Netherlands } \\
1,356\end{array}$ & $\begin{array}{c}\text { Portugal } \\
1,286\end{array}$ & $\begin{array}{l}\text { Spain } \\
1,367\end{array}$ & $\begin{array}{c}\text { All } \\
\text { countries } \\
9,344\end{array}$ \\
\hline Town or small city & $495(36 \cdot 7 \%)$ & $\begin{array}{c}224 \\
(17 \cdot 7 \%)\end{array}$ & $419(30 \cdot 8 \%)$ & $\begin{array}{c}526 \\
(39 \cdot 0 \%)\end{array}$ & $311(23 \cdot 0 \%)$ & $\begin{array}{c}368 \\
(28.6 \%)\end{array}$ & $589(43 \cdot 1 \%)$ & $\begin{array}{c}2932 \\
(31 \cdot 4 \%)\end{array}$ \\
\hline Country village & $287(21 \cdot 3 \%)$ & $\begin{array}{c}591 \\
(46 \cdot 6 \%)\end{array}$ & $301(22 \cdot 1 \%)$ & $\begin{array}{c}521 \\
(38 \cdot 6 \%)\end{array}$ & $578(42 \cdot 7 \%)$ & $\begin{array}{c}221 \\
(17 \cdot 2 \%)\end{array}$ & $401(29 \cdot 4 \%)$ & $\begin{array}{c}2900 \\
(31 \cdot 1 \%)\end{array}$ \\
\hline $\begin{array}{l}\text { Farm or home in } \\
\text { countryside }\end{array}$ & $66(4.9 \%)$ & $\begin{array}{c}165 \\
(13 \cdot 0 \%)\end{array}$ & $85(6 \cdot 2 \%)$ & $34(2 \cdot 5 \%)$ & $103(7 \cdot 6 \%)$ & $54(4 \cdot 2 \%)$ & $52(3 \cdot 8 \%)$ & $559(6 \cdot 0 \%)$ \\
\hline \multicolumn{9}{|l|}{ Marital status } \\
\hline $\begin{array}{l}\text { Married or with a } \\
\text { partner }\end{array}$ & $822(61 \cdot 3 \%)$ & $\begin{array}{c}951 \\
(75 \cdot 7 \%)\end{array}$ & $784(58 \cdot 1 \%)$ & $\begin{array}{c}860 \\
(63 \cdot 8 \%)\end{array}$ & $932(69 \cdot 2 \%)$ & $\begin{array}{c}814 \\
(63.6 \%)\end{array}$ & $847(62 \cdot 2 \%)$ & $\begin{array}{c}6010 \\
(64 \cdot 8 \%)\end{array}$ \\
\hline $\begin{array}{l}\text { Divorced or } \\
\text { separated }\end{array}$ & $175(13 \cdot 1 \%)$ & $100(8 \cdot 0 \%)$ & $152(11 \cdot 3 \%)$ & $86(6 \cdot 4 \%)$ & $110(8 \cdot 2 \%)$ & $91(7 \cdot 1 \%)$ & $100(7 \cdot 3 \%)$ & $814(8 \cdot 8 \%)$ \\
\hline Widowed & $131(9 \cdot 8 \%)$ & $96(7 \cdot 6 \%)$ & $83(6 \cdot 2 \%)$ & $92(6 \cdot 8 \%)$ & $142(10 \cdot 5 \%)$ & $109(8.5 \%)$ & $113(8 \cdot 3 \%)$ & $766(8 \cdot 3 \%)$ \\
\hline Single & $212(15 \cdot 8 \%)$ & $110(8 \cdot 8 \%)$ & $330(24 \cdot 5 \%)$ & $\begin{array}{c}310 \\
(23 \cdot 0 \%)\end{array}$ & $162(12 \cdot 0 \%)$ & $\begin{array}{c}265 \\
(20 \cdot 7 \%)\end{array}$ & $301(22 \cdot 1 \%)$ & $\begin{array}{c}1690 \\
(18 \cdot 2 \%)\end{array}$ \\
\hline \multicolumn{9}{|l|}{ Religion } \\
\hline Yes & $778(57 \cdot 9 \%)$ & $\begin{array}{c}664 \\
(52 \cdot 9 \%)\end{array}$ & $771(57 \cdot 0 \%)$ & $\begin{array}{c}1094 \\
(81 \cdot 6 \%)\end{array}$ & $616(45 \cdot 6 \%)$ & $\begin{array}{c}1017 \\
(79 \cdot 6 \%)\end{array}$ & $959(71 \cdot 0 \%)$ & $\begin{array}{c}5899 \\
(63 \cdot 6 \%)\end{array}$ \\
\hline \multicolumn{9}{|l|}{ Health } \\
\hline Very good & $565(42 \cdot 0 \%)$ & $\begin{array}{c}490 \\
(38 \cdot 6 \%)\end{array}$ & $310(22 \cdot 9 \%)$ & $\begin{array}{c}305 \\
(22 \cdot 6 \%)\end{array}$ & $302(22 \cdot 3 \%)$ & $\begin{array}{c}170 \\
(13 \cdot 3 \%)\end{array}$ & $293(21 \cdot 5 \%)$ & $\begin{array}{c}2435 \\
(26 \cdot 1 \%)\end{array}$ \\
\hline Good & $535(39.8 \%)$ & $\begin{array}{c}583 \\
(46 \cdot 0 \%)\end{array}$ & $699(51 \cdot 5 \%)$ & $\begin{array}{c}642 \\
(47 \cdot 6 \%)\end{array}$ & $748(55 \cdot 3 \%)$ & $\begin{array}{c}488 \\
(38 \cdot 1 \%)\end{array}$ & $560(41 \cdot 1 \%)$ & $\begin{array}{c}4255 \\
(45.7 \%)\end{array}$ \\
\hline Fair & $191(14 \cdot 2 \%)$ & $\begin{array}{c}176 \\
(13 \cdot 9 \%)\end{array}$ & $289(21 \cdot 3 \%)$ & $\begin{array}{c}377 \\
(28 \cdot 0 \%)\end{array}$ & $254(18 \cdot 8 \%)$ & $\begin{array}{c}558 \\
(43 \cdot 6 \%)\end{array}$ & $437(32 \cdot 0 \%)$ & $\begin{array}{c}2282 \\
(24 \cdot 5 \%)\end{array}$ \\
\hline Bad & $47(3 \cdot 5 \%)$ & $16(1 \cdot 3 \%)$ & $53(3 \cdot 9 \%)$ & $21(1.6 \%)$ & $43(3 \cdot 2 \%)$ & $46(3.6 \%)$ & $67(4 \cdot 9 \%)$ & $293(3.1 \%)$ \\
\hline Very bad & $7(0.5 \%)$ & $3(0 \cdot 2 \%)$ & $5(0 \cdot 4 \%)$ & $3(0 \cdot 2 \%)$ & $5(0 \cdot 4 \%)$ & $19(1.5 \%)$ & $7(0 \cdot 5 \%)$ & $49(0 \cdot 5 \%)$ \\
\hline $\begin{array}{l}\text { Experience of } \\
\text { illness, death and } \\
\text { dying }\end{array}$ & & & & & & & & \\
\hline
\end{tabular}




\begin{tabular}{|c|c|c|c|c|c|c|c|c|}
\hline $\mathrm{n}$ & $\begin{array}{c}\text { England } \\
1,351\end{array}$ & $\begin{array}{c}\text { Flanders } \\
1,269\end{array}$ & $\begin{array}{c}\text { Germany } \\
1,363\end{array}$ & $\begin{array}{l}\text { Italy } \\
1,352\end{array}$ & $\begin{array}{c}\text { Netherlands } \\
1,356\end{array}$ & $\begin{array}{c}\text { Portugal } \\
1,286\end{array}$ & $\begin{array}{l}\text { Spain } \\
1,367\end{array}$ & $\begin{array}{c}\text { All } \\
\text { countries } \\
9,344 \\
\end{array}$ \\
\hline $\begin{array}{l}\text { Diagnosed with } \\
\text { serious illness in } \\
\text { last } 5 \text { years }\end{array}$ & $172(12 \cdot 8 \%)$ & $\begin{array}{c}190 \\
(15 \cdot 2 \%)\end{array}$ & $107(8.0 \%)$ & $113(8.4 \%)$ & $137(10 \cdot 1 \%)$ & $99(7 \cdot 8 \%)$ & $119(8.8 \%)$ & $\begin{array}{c}937 \\
(10.1 \%)\end{array}$ \\
\hline $\begin{array}{l}\text { Close } \\
\text { relative/friend } \\
\text { seriously ill in last } \\
5 \text { years }\end{array}$ & $849(63 \cdot 1 \%)$ & $\begin{array}{c}760 \\
(60 \cdot 6 \%)\end{array}$ & $862(64 \cdot 1 \%)$ & $\begin{array}{c}900 \\
(67 \cdot 4 \%)\end{array}$ & $969(71 \cdot 8 \%)$ & $\begin{array}{c}728 \\
(57 \cdot 5 \%)\end{array}$ & $923(68.2 \%)$ & $\begin{array}{c}5991 \\
(64.8 \%)\end{array}$ \\
\hline $\begin{array}{l}\text { Death of close } \\
\text { relative/friend in } \\
\text { last } 5 \text { years }\end{array}$ & $949(70 \cdot 6 \%)$ & $\begin{array}{c}876 \\
(69.9 \%)\end{array}$ & $933(69 \cdot 4 \%)$ & $\begin{array}{c}928 \\
(69 \cdot 3 \%)\end{array}$ & $1036(76 \cdot 7 \%)$ & $\begin{array}{c}771 \\
(60 \cdot 9 \%)\end{array}$ & $\begin{array}{c}1006 \\
(74.4 \%)\end{array}$ & $\begin{array}{c}6499 \\
(70.3 \%)\end{array}$ \\
\hline $\begin{array}{l}\text { Cared for close } \\
\text { relative/friend in } \\
\text { last months of life }\end{array}$ & $679(50 \cdot 6 \%)$ & $\begin{array}{c}625 \\
(49 \cdot 9 \%)\end{array}$ & $647(48 \cdot 0 \%)$ & $\begin{array}{c}815 \\
(60 \cdot 8 \%)\end{array}$ & $702(52 \cdot 0 \%)$ & $\begin{array}{c}673 \\
(53 \cdot 2 \%)\end{array}$ & $771(57.0 \%)$ & $\begin{array}{c}4912 \\
(53.1 \%)\end{array}$ \\
\hline
\end{tabular}

Legend: Sums may not always amount to the total sample number because of missing values on variables. Percentages may not always add up to 100 because of rounding. $\mathrm{SD}=$ standard deviation. 
Table 2: Preferences by country for information on time left, likely symptoms and problems, and care options available (\%)

\begin{tabular}{|c|c|c|c|c|c|c|c|c|c|}
\hline $\begin{array}{l}\text { Would want } \\
\text { to know about }\end{array}$ & $\begin{array}{l}\text { Answer } \\
\text { options }\end{array}$ & $\begin{array}{c}\text { England } \\
1,351\end{array}$ & $\begin{array}{c}\text { Flanders } \\
1,269\end{array}$ & $\begin{array}{c}\text { Germany } \\
1,363\end{array}$ & $\begin{array}{l}\text { Italy } \\
1,352\end{array}$ & $\begin{array}{c}\text { Netherlands } \\
1,356\end{array}$ & $\begin{array}{c}\text { Portugal } \\
1,286\end{array}$ & $\begin{array}{l}\text { Spain } \\
1,367\end{array}$ & $\begin{array}{c}\text { All countries } \\
9,344\end{array}$ \\
\hline \multirow[t]{4}{*}{ Time left } & Always & 77.0 & 80.7 & 75.0 & 67.6 & 74.1 & 73.5 & 70.1 & 73.9 \\
\hline & If I ask & 16.2 & 7.3 & 14.1 & 19.8 & 16.3 & 9.3 & 11.6 & 13.6 \\
\hline & No & 5.2 & 6.0 & 5.6 & 7.3 & 6.8 & 10.6 & 11.4 & 7.5 \\
\hline & Don’t know & 1.6 & 6.1 & 5.3 & 5.4 & 2.8 & 6.6 & 7.0 & 5.0 \\
\hline \multirow[t]{4}{*}{ Symptoms } & Always & 80.0 & 87.2 & 78.0 & 76.9 & 77.3 & 89.6 & 80.6 & 81.3 \\
\hline & If I ask & 15.0 & 5.3 & 15.2 & 16.4 & 14.6 & 5.1 & 11.7 & 12.0 \\
\hline & No & 3.9 & 4.1 & 4.0 & 4.8 & 6.7 & 2.6 & 5.3 & 4.5 \\
\hline & Don’t know & 1.1 & 3.4 & 2.8 & 1.9 & 1.4 & 2.7 & 2.4 & 2.2 \\
\hline \multirow[t]{4}{*}{ Care options } & Always & 91.3 & 91.9 & 87.8 & 88.5 & 82.8 & 94.9 & 90.1 & 89.5 \\
\hline & If I ask & 6.4 & 5.0 & 8.6 & 9.0 & 12.9 & 2.7 & 5.3 & 7.2 \\
\hline & No & 2.0 & 2.1 & 1.8 & 1.9 & 3.3 & 0.8 & 1.8 & 2.0 \\
\hline & Don't know & 0.4 & 1.1 & 1.8 & 0.6 & 1.0 & 1.7 & 2.9 & 1.4 \\
\hline
\end{tabular}


Table 3 Crude percentages of wish to know about time left by covariates and countries

\begin{tabular}{|c|c|c|c|c|c|c|c|c|}
\hline & England & Flanders & $\begin{array}{c}\text { German } \\
\mathbf{y}\end{array}$ & Italy & $\begin{array}{c}\text { Netherlan } \\
\text { ds }\end{array}$ & Portugal & Spain & $\begin{array}{c}\text { All } \\
\text { countries }\end{array}$ \\
\hline \multicolumn{9}{|l|}{ Socio-demographic variables } \\
\hline Age bands & & $*$ & & & $*$ & $*$ & & $* * *$ \\
\hline $16-29$ & 76.6 & 81.8 & 69.8 & 67.8 & 67.2 & 79.9 & 71.1 & 73.0 \\
\hline $30-39$ & 82.1 & 79.0 & 74.4 & 69.3 & 70.4 & 74.9 & 74.7 & 74.8 \\
\hline $40-49$ & 80.8 & 85.4 & 76.6 & 65.2 & 77.2 & 75.2 & 70.6 & 76.0 \\
\hline $50-59$ & 74.0 & 81.3 & 78.7 & 67.2 & 78.5 & 71.0 & 68.2 & 74.4 \\
\hline $60-69$ & 78.1 & 78.5 & 76.8 & 64.4 & 74.5 & 73.0 & 71.1 & 74.2 \\
\hline $70+$ & 71.7 & 71.9 & 71.4 & 64.4 & 65.7 & 63.4 & 63.0 & 67.5 \\
\hline Gender & $*$ & $*$ & $*$ & $*$ & & $*$ & $*$ & $* * *$ \\
\hline Male & 80.6 & 77.1 & 78.0 & 71.7 & 75.2 & 77.8 & 74.0 & 76.5 \\
\hline Female & 74.9 & 82.7 & 72.9 & 66.0 & 73.6 & 71.6 & 68.2 & 72.6 \\
\hline Marital status & & & & & & & $*$ & $* *$ \\
\hline Married or with civil partner & 78.7 & 81.4 & 76.9 & 68.2 & 74.5 & 72.5 & 69.0 & 74.5 \\
\hline Divorced or separated & 75.4 & 82.0 & 72.9 & 65.9 & 79.1 & 79.1 & 77.0 & 75.9 \\
\hline Widowed & 68.7 & 78.1 & 67.1 & 72.8 & 68.1 & 67.9 & 62.0 & 69.0 \\
\hline Single & 76.8 & 76.4 & 74.1 & 64.5 & 74.1 & 76.6 & 73.8 & 73.2 \\
\hline Highest level of education & $*$ & $* *$ & & & $*$ & & $* *$ & $* * *$ \\
\hline Up to 16 & 68.8 & 65.4 & 33.3 & 40.0 & 58.3 & 66.7 & 60.2 & 64.3 \\
\hline $16-18$ & 78.2 & 78.8 & 74.5 & 68.0 & 72.3 & 73.5 & 68.5 & 72.8 \\
\hline $18+$ & 78.0 & 84.0 & 76.6 & 65.8 & 78.1 & 73.9 & 75.9 & 77.0 \\
\hline Financial hardship & & & & & & & & $* *$ \\
\hline $\begin{array}{l}\text { Difficult or very difficult on present } \\
\text { income }\end{array}$ & 74.7 & 79.4 & 71.8 & 68.3 & 70.7 & 76.3 & 66.8 & 72.1 \\
\hline Coping on present income & 74.6 & 78.8 & 77.5 & 68.9 & 73.2 & 72.3 & 68.8 & 73.2 \\
\hline Living comfortably on present income & 80.2 & 82.3 & 73.4 & 65.1 & 75.1 & 73.9 & 74.0 & 75.6 \\
\hline \multicolumn{9}{|l|}{ Value / preference-based variables } \\
\hline Most concerning problem & & & & $*$ & & $*$ & & \\
\hline
\end{tabular}




\begin{tabular}{|c|c|c|c|c|c|c|c|c|}
\hline Social focussed concern & 76.1 & 81.4 & 75.7 & 71.2 & 74.3 & 79.1 & 71.4 & 74.9 \\
\hline Physical/psychological concern & 77.8 & 81.0 & 74.8 & 65.5 & 74.1 & 72.6 & 70.2 & 74.1 \\
\hline Quantity/quality of life & & & & & & & & $* *$ \\
\hline Extend life & 63.3 & 74.6 & 74.5 & 63.9 & 71.7 & 78.2 & 69.1 & 71.8 \\
\hline Both are equally important & 75.2 & 78.1 & 71.7 & 66.0 & 68.9 & 74.1 & 71.4 & 71.7 \\
\hline To improve the quality of time left & 78.0 & 82.0 & 77.4 & 68.7 & 76.0 & 73.5 & 70.4 & 75.2 \\
\hline \multicolumn{9}{|l|}{ Preferred place of death } \\
\hline Own home/ home of relative or friend & 78.7 & 79.2 & 76.4 & 67.5 & 74.5 & 73.7 & 70.6 & 74.2 \\
\hline Hospice or palliative care unit & 76.9 & 84.4 & 75.1 & 69.2 & 72.5 & 76.1 & 73.8 & 75.5 \\
\hline Hospital - but not a palliative care unit & 73.8 & 83.5 & 64.4 & 67.1 & 72.1 & 67.3 & 70.0 & 72.4 \\
\hline Nursing home or residential home & 65.4 & 87.5 & 75.0 & 63.6 & 81.8 & 73.1 & 51.4 & 72.9 \\
\hline Somewhere else & 56.5 & 66.7 & 78.0 & 66.7 & 88.9 & 78.8 & 66.7 & 71.4 \\
\hline \multicolumn{9}{|l|}{ Experiential variables } \\
\hline $\begin{array}{l}\text { Self diagnosed with serious illness in } \\
\text { last } 5 \text { years }\end{array}$ & & & & & * & & & $* *$ \\
\hline Yes & 83.7 & 80.4 & 78.3 & 73.2 & 77.4 & 77.6 & 69.5 & 77.8 \\
\hline No & 75.9 & 80.8 & 74.8 & 67.2 & 73.8 & 73.1 & 70.4 & 73.6 \\
\hline $\begin{array}{l}\text { Close relative / friend diagnosed with } \\
\text { serious illness in the last } 5 \text { years }\end{array}$ & & $* *:$ & & & & & & * \\
\hline Yes & 77.8 & 84.2 & 76.2 & 66.4 & 74.1 & 75.0 & 71.6 & 74.8 \\
\hline No & 75.2 & 75.5 & 72.8 & 71.0 & 74.3 & 71.4 & 67.3 & 72.5 \\
\hline
\end{tabular}

Note: Sums may not always amount to the totals because of missing values on variables. $* \mathrm{p}<0 \cdot 05 . * * \mathrm{p}<0 \cdot 01 * * *<0.001$ 
Table 4: Multivariate logit model of wish to know about time left

\begin{tabular}{lccccc}
\hline \multicolumn{1}{c}{ Covariate } & Reference group & OR & $\mathbf{9 5 \%} \mathbf{C I}$ & $\mathbf{Z}$ & $\mathbf{p}$ \\
\hline Age & $16-69$ & 0.72 & 0.62 to 0.83 & -4.44 & $<0.001$ \\
Gender & Female & 1.23 & 1.10 to 1.37 & 3.77 & $<0.001$ \\
Education & $16-18$ & 1.20 & 1.09 to 1.32 & 3.83 & $<0.001$ \\
Serious illness & No & 1.20 & 1.01 to 1.43 & 2.05 & 0.040 \\
Relative's illness & No & 1.12 & 1.01 to 1.24 & 2.15 & 0.032 \\
Quantity or & Quantity & 1.13 & 1.03 to 1.24 & 2.69 & 0.007 \\
quality of life & & & & & \\
\hline
\end{tabular}

Table 5: Associations between information preference items

\begin{tabular}{llccccccccc}
\hline $\begin{array}{c}\text { Preference to } \\
\text { know ... }\end{array}$ & $\mathbf{N}$ & \multicolumn{3}{c}{ Symptoms \% } & \multicolumn{5}{c}{ Care\% } \\
\hline \multirow{3}{*}{ Time } & Always & 6880 & 92.0 & 5.3 & 1.7 & 1.1 & 94.2 & 4.1 & 1.0 & 0.7 \\
left & If I ask & 1264 & 53.5 & 41.6 & 3.3 & 1.6 & 79.4 & 18.3 & 1.0 & 1.3 \\
& No & 699 & 41.8 & 20.5 & 31.9 & 5.9 & 67.1 & 15.7 & 13.3 & 3.9 \\
& D/K & 460 & 58.2 & 18.8 & 7.4 & 15.5 & 81.3 & 9.6 & 1.5 & 7.6 \\
Care & Always & 8338 & 86.5 & 9.4 & 2.6 & 1.6 & - & - & - & - \\
& If I ask & 666 & 38.1 & 46.1 & 12.0 & 3.8 & - & - & - & - \\
& No & 181 & 30.9 & 7.2 & 56.4 & 5.5 & - & - & - & - \\
& D/K & 125 & 39.2 & 12.8 & 15.2 & 32.8 & - & - & - & - \\
\hline
\end{tabular}

$\mathrm{D} / \mathrm{K}=$ don't know. 


\section{Appendix (Supplementary Data)}

- Survey questionnaire (English version)

- Table A. Bivariate analysis: tests and variables 